\title{
Is the effect the same every January? Seasonality and Brazilian equity fund flows
}

\author{
Janaína Cássia Grossi \\ (D) https://orcid.org/0000-0002-4070-3275 \\ Email: janainagrossi_3@hotmail.com \\ Rodrigo Fernandes Malaquias ${ }^{1}$ \\ (D) https://orcid.org/0000-0002-7126-1051 \\ Email: rodrigofmalaquias@ufu.br
}

${ }^{1}$ Universidade Federal de Uberlândia, Faculdade de Gestão e Negócios, Departamento de Finanças, Uberlândia, MG, Brazil

Received on 01.18.2019 - Desk acceptance on 02.18.2019 - 3rd version approved on 08.08.2019 - Ahead of print on 12.09.2019

Associate Editor: Fernanda Finotti Cordeiro Perobelli

\begin{abstract}
Based on the assumption that seasonal patterns have been identified in stock market assets and also in the context of equity mutual funds, the aim of this research is to investigate the relationship between the seasonality presented by the January effect and the net flow of Brazilian equity funds. The study extends the potential effects of seasonality beyond the return on stock market assets, demonstrating that seasonal patterns can also be observed in Brazilian mutual fund flows. The literature mostly points to common factors related to the performance of equity mutual funds; therefore this study investigates mutual fund flows, demonstrating that different factors influence the decisions of fund investors, including seasonal factors. The study has practical implications for fund managers, as it highlights a set of variables that can be used to anticipate variations in fund flow, reducing their effects on performance and avoiding costs. The results were estimated using panel data regression analysis. The study sample consisted of 1,010 equity funds, covering the period from January of 2004 to June of 2018. It was found that the average net inflow of Brazilian equity mutual funds is higher in January than in other months of the year, which characterizes the existence of a seasonal pattern in their net flows. However, the effect is different between exclusive and non-exclusive funds. As contributions, our findings: (i) provide a better understanding about the factors related to investor decision-making; (ii) point out new aspects in which exclusive and non-exclusive funds differ; and (iii) present factors that influence mutual fund flows.
\end{abstract}

Keywords: seasonality, mutual fund flows, exclusive and non-exclusive funds.

Correspondence address

Rodrigo Fernandes Malaquias

Universidade Federal de Uberlândia, Faculdade de Gestão e Negócios, Departamento de Finanças

Avenida João Naves de Ávila, 2121, Bloco 1F, Sala 1F-216 - CEP 38400-902

Campus Santa Mônica - Uberlândia - MG - Brasil 


\section{INTRODUCTION}

At the start of 2018, the amount of net equity under the management of Brazilian equity mutual funds represented more that $60 \%$ of the country's gross domestic product (GDP) for 2017, that is, R $\$ 4.3$ trillion. In terms of net inflow, in 2017, the segment captured a total of R $\$ 266.4$ billion (Brazilian Association of Financial and Capital Market Entities [Associação Brasileira das Entidades dos Mercados Financeiro e de Capitais - Anbima], 2018). The following questions arise: What factors are related to the intense Brazilian mutual fund flows? What influences the decision of investors to invest or redeem resources in a particular fund? Could seasonal aspects influence investor behavior?

From an investor perspective, international studies suggest that both characteristics that are inherent to equity mutual funds, such as size, age, past performance, the fund's family, and performance fee (Barber, Odean, \& Zheng, 2005; Berggrun \& Lizarzaburu, 2015; Chevalier \& Ellison, 1997; Ferreira, Keswani, Miguel, \& Ramos, 2012; Sirri \& Tufano, 1998), and factors that are extrinsic to them, such as macroeconomic variables and investor sentiment (Chalmers, Kaul, \& Phillips, 2013; Ferson \& Kim, 2012; Krishnamurthy, Pelletier, \& Warr, 2018), exert an influence on investor decisions to invest in or redeem shares in equity mutual funds.

Interestingly, it is even suggested that idiosyncratic components, such as seasonality and/or calendar effects, have a relationship with variations in fund flows (Choi, 2015; Choi, Ryu, \& Seok, 2017; Kamstra, Kramer, Levi, $\&$ Wermers, 2017), when, for example, investors migrate their shares in mutual funds of different categories and classes of risk according to the seasons of the year or when they tend to rebalance their portfolios at the turn of the year.

Patterns such as those that have been found are considered seasonal calendar effects, as they concern predictable variations in relation to the behavior of financial assets at regular calendar intervals (Al-Khazali, Koumanakos, \& Pyun, 2008). Such effects are not consistent with the market efficiency assumptions and are not decisions based on the rationality of investors (Keim, 1983).

Among the seasonalities already identified in the stock market between the months of January and December, it has been found that the average return on stocks is greater in the month of January than in other months of the year, which has been called the "January effect" (Al-Khazali \& Mirzaei, 2017). In equity mutual funds, the seasonality presented by the January effect has been identified in the return of British equity funds (VidalGarcía \& Vidal, 2014) and also in the net flow of US funds (Choi, 2015; Choi et al., 2017). For the case of Brazilian funds, there still appears to be room for debate regarding this topic, which was also one of the reasons for carrying out this study.

It is suggested that the January effect on fund flows could be related with the increase in income and consumption of investors at the end of the year, to the performance of equity mutual funds in the month of December, to the tax treatment of the investor based on the capital distributions of funds (Choi et al., 2017), a reflection of the seasonal pattern of the stock market or of fund performance, or could even be due to a behavioral component of fund investors, since most of these would make their investment decisions and revise their portfolios at the turn of the year (Choi, 2015).

Although the literature on the seasonality presented in the month of January concentrates on the stock market (Al-Khazali \& Mirzaei, 2017; Caporale \& Zakirova, 2017; Easterday \& Sen, 2016; Seif, Docherty, \& Shamsuddin, 2017; Shiu, Lee, \& Gleason, 2014), this seasonal effect can also be observed in equity mutual funds that allocate most of the assets of their portfolios in the stock market (Malaquias \& Mamede, 2015), such as Brazilian equity funds, which invest at least $67 \%$ of their equity in stocks (Brazilian Securities and Exchange Commission [Comissão de Valores Mobiliários - CVM], 2014).

Therefore, considering the fact that investors in equity funds may redeem or invest in shares in these funds according to their expectations, in response to changes in the financial market, as well as with the aim of revising their resource allocation, it is conjectured that the seasonality of the month of January might also be observed in Brazilian stock funds, thus explaining, at least in part, differences in the net inflow of these funds every January.

It is also suggested that the seasonality effect presented in January may be different according to the characteristics of the funds. In Brazil, for example, one specific type is the exclusive fund, in which the total equity invested is derived from a single investor, which contributes a minimum value of R $\$ 10$ million (CVM, 2014), while in non-exclusive funds the investors are fragmented and there may not be a minimum investment requirement. Given the divergences between these two types of funds, differences in seasonal patterns may also be observed. 
To explore such aspects, this study: (i) examines the relationship between the seasonality of the month of January and equity fund flows in Brazil, verifying whether the average net inflow of funds is greater in January than in other months of the year; and (ii) verifies whether the January effect on net inflow is different in exclusive and non-exclusive funds.

The sample of this study covers around 1,010 stock funds per year (900 non-exclusive and 110 exclusive) in the period from January of 2004 to June of 2018. Multiple linear regression analysis with panel data will be used to test the hypotheses.

This study provides contributions to the literature and also presents practical implications for fund managers, investors, and policymakers: (i) it offers a better understanding regarding the behavior of investors in equity funds and relevant factors for their investment decision-making; (ii) it demonstrates the possible effect of monetary policy on the allocation of resources in mutual funds; (iii) it presents factors that influence fund flows, as the literature mostly indicates common factors related to fund performance; (iv) it indicates new aspects in which exclusive and non-exclusive funds differ; (v) it highlights a set of variables that fund managers can use to anticipate variations in net flow and reduce their effects on performance; (vi) it demonstrates that the investment decisions of fund shareholders are related both to rational and non-rational aspects, which broadens the evidence indicated by the theory of behavioral finance.

\section{THEORETICAL FRAMEWORK}

Behavioral patterns in the assets that compose the financial market have been revealed by the literature (Al-Khazali \& Mirzaei, 2017; Caporale \& Zakirova, 2017; Easterday \& Sen, 2016; Seif et al., 2017; Shiu et al., 2014) and are considered anomalies of the financial market, as they are not consistent with the market efficiency assumptions and are not based on rational decisions of economic agents (Keim, 1983). The effects of these anomalies are predictable variations in the behavior and/ or return of financial assets at regular calendar intervals, such as a particular day of the week, a specific month, or a seasonal period (Al-Khazali et al., 2008), presenting the possibility for investors to make predictions (Al-Khazali \& Mirzaei, 2017).

Among the studies that relate financial behavioral patterns and calendar, it has been revealed possible seasonal behavior in the stock market between the months of January and December, such that the average return on stocks would be greater in the month of January than in other months of the year, which has become known as the January effect (Thaler, 1987).

The January effect was documented for the first time in the 1940s, when Sidney B. Wachtel (1942) used the Dow Jones Industrial Average index in the period from 1927 to 1942 in the search for possible seasonal behavior in stock prices. From 1942 onward, subsequent studies on the January effect have mainly been disseminated in the United States of America (USA), with the aim of revealing the effect on the U.S. financial market (Keim, 1983; Rozeff \& Kinney, 1976; Thaler, 1987); later, the phenomenon was revealed at a global level (Agrawal \& Tandon, 1994; M. N. Gultekin \& N. B. Gultekin, 1983).
In the Brazilian stock market, the first studies regarding a possible January effect did not find statistical evidence of abnormal returns in that period of the year (Costa, 1990; Costa, \& O'Hanlon, 1991). Since the 2000s, studies have indicated the existence of seasonal patterns in the month of January in the Ibovespa index (Santos, Famá, Trovão, \& Mussa, 2007) and also in a sample of portfolios weighted by value, in which returns in January tended to be higher than in other months (Torres, Bonomo, \& Fernandes, 2002). Among the companies belonging to the Corporate Governance Index (Índice de Governança Corporativa IGC) of the B3 exchange, no indications were observed of temporal patterns in the month of January (Carvalho \& Malaquias, 2012). In a more recent study, the January effect was revealed and it was also found that it is more intense the more the negative return in the month of December increases (A. S. Potin, S. Potin, Cunha, \& Bortolon, 2015).

Although the literature on seasonality, such as the January effect, concentrates on the stock market (AlKhazali \& Mirzaei, 2017; Caporale \& Zakirova, 2017; Easterday \& Sen, 2016; Seif et al., 2017; Shiu et al., 2014), Malaquias and Mamede (2015) argue that part of the assets that compose the financial market are the shares of mutual funds, which may also be affected by certain seasonal effects of the stock market if most of the portfolios of these funds are invested in stocks.

However, only recently has the possibility of the occurrence of seasonality in the fund industry been the object of studies (Alves, 2014; Białkowski, Bohl, Kaufmann, \& Wisniewski, 2013; Brown, Sotes-Paladino, Wang, \& Yao, 2017; Choi, 2015; Choi et al., 2017; Gallagher \& Pinnuck, 
2006; Kamstra et al., 2017; Malaquias \& Mamede, 2015; Mamede \& Malaquias, 2017; Matallín-Sáez, 2006; VidalGarcía \& Vidal, 2014).

Most of the abovementioned articles investigate seasonal patterns in the return of funds. Gallagher and Pinnuck (2006) find that Australian funds tend to have greater performance in the months when there are company announcements and in the month of December; however, performance tends to be lower than the mean at the end of the country's fiscal year. In Spain, MatallínSáez (2006) suggests that positive abnormal returns are observed at the end of the year, at the end of each month, and at the beginning of July. Alves (2014) reveals that the performance of Eurozone funds is usually greater than the mean in the first half of the year.

Based on the assumption that in Ramadan (the ninth month of the Islamic calendar, when Muslims practice sacred fasting and prey more frequently) the stock market return is higher than in other months of the year, Białkowski et al. (2013) investigate whether managers of Turkish funds are able to benefit from this seasonality. The results indicate that domestic institutional funds and large hybrid domestic funds tend to have a higher return in Ramadan. In the USA, Brown et al. (2017) indicate the existence of quarterly seasonality, where in the first month of each quarter fund returns are negative. Malaquias and Mamede (2015) and Mamede and Malaquias (2017) revealed the Monday effect in Brazilian multimarket funds, such that the mean return of these funds was statistically lower on Mondays than on other days of the week. While the former revealed that the low Monday returns are intensified in periods of high inflation, the latter demonstrated intensity in crisis periods and explained the anomaly as being due to the bad news published on Fridays or at the weekends and also to the information asymmetry bias, which are factors that are inherent to the theory of behavioral finance.

Vidal-García and Vidal (2014), in turn, found evidence of seasonality in all the categories of British funds in the months of January, February, April, and May, when returns are positive. The results showed a positive relationship between seasonality and tax collection at the end of the fiscal year.

Besides the seasonality in the return of mutual funds, recent studies investigate the potential existence of seasonal patterns in fund flows. Kamstra et al. (2017), for example, use a sample of mutual funds from the USA, Canada, and Australia to analyze the flow of shares in funds between funds of different classes of risks in the spring and in the fall. The results indicated that investors tend to migrate their shares from relatively lower-risk investment categories in the fall to higher-risk categories in the spring. For the authors, the change in investor behavior is related to the change in temperature and to the amount of light, which influences the mood of individuals.

Choi (2015) believes in the existence of a seasonal component in investor behavior - which is studied by the author via an analysis of the net flow of U.S. funds. According to the study, as December is the month at the end of the financial year of most firms and also of individual investors, investors would be expected to be induced to revise their resource allocation in this period. In fact, the results show that the country's mutual funds receive a greater volume of net inflow in January, due to the increased purchases of shares in funds, and a lower amount in December, due to the increase in redemptions. Therefore, the turn of the year would be the period in which most fund investors would make their investment decisions.

As a second hypothesis of the study, Choi (2015) also argues that if investors decide to buy or sell shares in funds based on market performance, the seasonal pattern in fund flow may simply be a reflection of the seasonal pattern of the stock market. In addition, the seasonality of net inflow may also be related to the seasonality of fund performance, as some studies document the existence of a relationship between fund flow and performance. According to the results, there is a positive and statistically significant relationship between performance in $t$ and in $t-1$ and the net inflow of fund; that is, in funds with higher returns, share purchases would increase and redemptions would decrease.

Along the same lines, Choi et al. (2017) also investigate the occurrence of seasonalities in the net inflow of U.S. funds - at the turn of the year and at the start and end of each quarter. The authors suggest that the increase in income and consumption at the end of the year, the tax due to the distribution of capital of funds, the objective of funds, and past performance may be reasons related to such seasonalities.

Choi et al. (2017) found that net inflow is lower in December and higher in January. In January, purchases of new shares in funds are greater than redemptions, while in December redemptions are greater. The authors' results support the idea of Choi (2015) that investors tend to implement asset allocation decisions more intensely at the end of the year. As an explanation for the seasonality, the study suggests that the distribution of capital by funds would mean investors delayed buying new shares in funds with the aim of avoiding paying tax. Past fund performance would also be another possible explanation, as the net flow in January is greater for those funds that present 
high performance in December. Thus, it is conjectured in this study that the January effect, which has already been found in the stock market and in mutual funds in some countries, may also be extended to Brazilian stock funds, affecting their inflow and outflow of resources. In other words, this effect could cause variations in equity mutual fund flows. Therefore:

$\mathbf{H}_{\mathbf{1}}$ : Net inflow in the month of January is, on average, greater than net inflow in other months of the year.

\subsection{Seasonality in Exclusive and Non-Exclusive Funds}

One specific type of fund present in the Brazilian fund industry is exclusive funds, which allow the total capital invested in the fund to originate from a single fund shareholder. For individual investors, companies, or entities to invest in exclusive funds, the minimum investment must be R 10 million (CVM, 2014).

Besides exclusive funds differing from non-exclusive funds in regard to the number of fund shareholders, their administration fee is also usually lower, as communicating with one shareholder is easier and quicker than with various (Varga \& Wengert, 2011). Recent studies also reveal other aspects that would differentiate the two categories of funds: Funchal, Lourenço, and Motoki (2016), for example, found that more sophisticated fund managers, such as those of exclusive funds, incur a lower risk on average when choosing the investment portfolio of these funds. Conversely, in funds with a more fragmented shareholding or less sophisticated investors, managers would have more freedom to take greater risks within what is stipulated in the regulations. The authors suggest that this difference would be a possible indication of agency problems.
Chen and Malaquias (2018) also reveal differences in the level of agency conflict between managers and principals of these two types of funds: managers responsible for administering exclusive and non-exclusive fund portfolios at the same time would tend to prioritize the interests of the exclusive fund investors, meaning the performance of these funds would be greater. The argument behind this preference may reside in the fact that "future business with wealthy exclusive fund shareholders is brighter if the fund performance is shining" (Chen \& Malaquias, 2018, p. 13).

Besides the difference in performance and risk between the two types of funds, as demonstrated in the studies by Chen and Malaquias (2018) and Funchal et al. (2016), it is conjectured in this study that another divergence between the two types of fund is the seasonality in the net inflow presented by the month of January. Since exclusive funds are meant for a specific type of investor - individual investors that invest large quantities of capital - these funds may be susceptible to smaller variations in net inflow than non-exclusive funds, in which investors are more fragmented. In addition, naturally, in the context of non-exclusive funds there are a greater number of investors inputting and redeeming sums over time, thus increasing the frequency of changes in net inflow.

Also, shareholders in exclusive funds are expected to consider their investments as being long term and hold their capital in these funds, unless an adversity occurs in their financial situation. Thus, notably at the start of the year, a potential rebalancing of investments, in response to occurrences in the market, would have a small effect over their decisions to alter their investments in exclusive funds. Therefore:

$\mathbf{H}_{2}$ : The January effect on the net inflow of exclusive funds does not present statistical significance.

\section{METHODOLOGY}

The sample was composed of around 1,010 equity funds per year; of these, 900 are non-exclusive and 110 are exclusive. To compose the final database, months with missing values for net equity and/or return were excluded, as well as funds and/or months with missing values in exclusive funds.

The analysis period was from January of 2004 to June of 2018. The data were collected from the ANBIMA Information System (SI-ANBIMA), from the Brazilian
Securities and Exchange (CVM) database, and from the Economática database.

The dependent variable, which concerns investment fund flow, was estimated using two metrics. The reason for using two metrics is to evaluate whether the results would be robust for different ways of measuring net inflow. The first metric is based on the study by Sirri and Tufano (1998), as shown in Equation 1. The metric has been used by other studies that have measured mutual fund flows 
(Brown et al., 2017; Chen \& Malaquias, 2018; Ferson \& Kim, 2012) and will be used to run the hypothesis tests.

$$
\operatorname{Net~Inflow~}_{i, t}=\frac{\operatorname{TotalNE}_{i, t}-\operatorname{TotalNE}_{i, t-1} x\left(1+R_{i, t}\right)}{\operatorname{TotalNE}_{i, t-1}}
$$

where TotalNE $E_{i, t}$ is the total net equity of fund $i$ at time $t$ and $R$ is the fund's return.

Regarding the second metric, this is based on the weighting of the monthly net inflow of each fund in the sample by its net equity in the previous month. In this case, net inflow represents the difference between inflow and redemptions occurring in the fund over the month; this value (in $t$ ) is then weighted by the fund's net equity (at the end of $t-1$ ), as according to Equation 2. This second metric will be used for the purposes of analyzing the robustness of the results obtained based on the proxy mentioned in the previous paragraph.

$$
\text { Monthly Net Inflow }=\frac{\text { Investment }_{t}-\text { Redemptions }_{t}}{\text { TotalN }_{t-1}}
$$

The independent variable, which captures a possible calendar anomaly in the month of January, corresponds to a dummy with the value 1 for the months of January and 0 for other months of the year.

According to studies on mutual fund flows, some variables may explain variations in investments and in redemptions of shares in funds; so these are treated as control variables in this study:

- Size of the Fund: measured by the Napierian logarithm of the fund's net equity in the month of analysis. Larger funds are expected to be able to attract more investments, as they have greater bargaining power, bigger economies of scale, and a lower administration fee (Barber et al., 2005; Chevalier \& Ellison, 1997; Ferreira et al., 2012; Sirri \& Tufano, 1998). The expected relationship is positive.

- Size of the Fund's Family: measured by the Napierian logarithm of the sum of the net equity in the month of analysis of all the funds affiliated with the family to which the fund in question belongs. This study considers "family" as being the funds that are controlled and managed by the same administrator company. Funds from large families receive more media attention and an investor that has shares in a fund of a given family is likely to more easily receive information on or know the other funds in the complex (Sirri \& Tufano, 1998). The expected relationship is positive.

- Age of the Fund: measured by the fund's age (in years) at the end of each month of the analysis. Barber et al. (2005), Chevalier and Ellison (1997), Ferreira et al.
(2012), and Sirri \& Tufano (1998) argue that more mature funds tend to attract more investments. The expected relationship is positive.

- Past Performance: this concerns the performance of fund $i$ in month $t-1$, which will be measured by the simple return. Investors look for favorable past performance, so they use recent available information regarding fund performance in their decision making, hoping that the good performance will be repeated (Goetzmann \& Peles, 1997). Ferreira et al. (2012) found that this behavior is even more evident in developing countries, such as Brazil, where investors have a lower degree of sophistication. Berggrun and Lizarzaburu (2015) confirm the search for past performance in the Brazilian equity fund market. The expected relationship is positive.

- Performance Fee: measured using a dummy that takes the value 1 if the fund charges a performance fee and 0 otherwise. Funds with higher performance fees tend to present higher returns (Ferreira et al., 2012; Mamede \& Malaquias, 2017), so from the investors' viewpoint, above-average return would offset the cost of the fee (Ippolito, 1989). In addition, performance fee is seen as an incentive that mitigates the conflict of interest that exists between investors and fund managers, aligning the manager and the fund shareholder's aim of obtaining higher returns (Ackermann, McEnally, \& Ravenscraft, 1999). The expected relationship is positive.

- Ibovespa Index: measured by the Ibovespa return, which may be one of the risk factors of Brazil that would influence the portfolio composition strategies of equity mutual funds (Maestri \& Malaquias, 2017). In addition, equity fund flows may be a reflection of stock market performance; as the shares quoted on the stock exchange increase in value, investors allocate their resources in funds that invest their capital in the stock market, believing that the fund managers would be able to capture these better returns (Choi et al., 2017). The expected relationship is positive.

- Interest Rate: represented by the monthly real interest rate of the Brazilian economy, the argument is that the lower the interest rate, the higher the investors' preference for high risk investments (Cecchetti, Genberg, Lipsky, \& Wadhwani, 2000). Hau and Lai (2016) explain that investors would accept taking on greater risk in their portfolios if low-risk investments provided insufficient returns, making them less risk averse; the authors showed that in countries with a falling interest rate, investors migrate their capital from more liquid and fixed income investments toward 
variable income and stock market investments. The expected relationship is negative.

- Inflation: represented by the Extended Consumer Price Index (Índice de Preços ao Consumidor Amplo - IPCA), which is the official index of the Federal Government for measuring inflationary targets. Studies indicate the negative impact of inflation on stock prices, since an increase in it indicates a decline in economic activity (Fama, 1981) and inflationary periods coincide with periods of individual uncertainty in relation to the economy, so investors are more risk averse (Brandt \& Wang, 2003). Considering investor expectations of a fall in stock prices due to an increase in inflation, Krishnamurthy et al. (2018) argue, therefore, that inflation affects individual asset allocation decisions, leading individuals to migrate their investments toward safer forms, such as bank deposits. The expected relationship is negative.

- Exchange Rate: measured by the monthly return on the commercial dollar. The demand of agents for external investments or domestic assets linked to foreign currencies is based on the expected rate of return on these assets, which, in turn, depends on variations in the exchange rate (Krugman, Obstfeld, \& Melitz, 2014). Ferson and Kim (2012) and Krishnamurthy et al. (2018) demonstrate that variations in the exchange rate have explanatory power regarding the net flow of different classes of US funds, since investors alter their portfolios between funds and assets of different classes of risk or linked to different forms of return according to exchange rate variations. The expected relationship is negative.

Most of the studies that investigate seasonality effects employ a panel data regression analysis using dummies in the seasonal periods to be tested in order to carry out the multiple regression estimates (Alves, 2014; Białkowski et al., 2013; Brown et al., 2017; Choi, 2015; Choi et al., 2017; Gallagher \& Pinnuck, 2006; Kamstra et al., 2017; Malaquias \& Mamede, 2015; Mamede \& Malaquias, 2017; Matallín-Sáez, 2006; Vidal-García \& Vidal, 2014). Therefore, the same statistical technique was used to test the research hypotheses. The panel used was unbalanced.
The statistical data were treated using the Stata software. The model of this study is shown in Equation 3:

$$
N I N F_{i, t}=\beta_{0}+\beta_{1} D J A N_{i, t}+\sum_{K=1}^{n} \lambda_{k} C V_{k i t}+\varepsilon_{i t}
$$

in which NINF is the Net Inflow; DJAN is the month of January dummy; $C V$ are the control variables; $\varepsilon_{i}=$ is the error term.

The occurrence of extreme data (outliers) in the net inflow variables ( 2 calculation metrics), past performance and age, was treated by means of winsorization at $1 \%$, $0.5 \%$ at each tail. To detect possible multicollinearity or autocorrelation, the variance inflation factor (VIF) and Durbin-Watson tests were carried out. To test whether the distribution is normal, the Shapiro-Wilk test was applied. The Breusch-Pagan, Chow, and Hausman tests suggest that the regression method that best fits the research model is the fixed effects method. The result of the Hausman test revealed that the fixed effects model was the most appropriate (chi $=204.67, p<0.01$ ). The result of the Breusch-Pagan test revealed that the random effects model was the most appropriate ( $\mathrm{chi}=2,327.71, p<0.01)$. The result of the Chow test revealed that the fixed effects model was the most appropriate $(\mathrm{F}=3.21, p<0.01)$.

With the aim of checking the robustness of the results found by the study, four new econometric models were estimated. The first of them used a different metric for net inflow, this being the net inflow in the month disclosed by the fund, weighted by the fund's net equity at the end of the previous month, as expressed in Equation 2. The second, third, and fourth models (Appendix C) evaluated whether the flows derived from the starting and/or closing of funds, or the funds that invest in shares in other funds (FICs), might not be responsible for the seasonality found in the month of January. For this, in the second model a subsample was considered of the funds starting and/or closing during the analysis period of the study; in the third model, a subsample was considered of the surviving funds in the period from 2004 to 2018; and, in the fourth model, a subsample of funds was considered from which the funds investing in shares in other funds were excluded. Models 2, 3, and 4 were estimated using the metric of Sirri and Tufano (1998) for the dependent variable Net Inflow. 


\section{RESULTS ANALYSIS}

The statistical description of the variables of the sample is presented in Table 1. During the analysis period, inflation, measured by the monthly IPCA, was negative in two observations, and the minimum value of -0.230 refers to the period of June 2006. Probably, in the months in question, the average price of the products that form part of the IPCA analysis basket fell in relation to the average for the other months. The monthly real interest rate also fell to a negative value in some months, and the lowest of all refers to the period of June 2018.

Table 1

Descriptive statistics of the variables

\begin{tabular}{|c|c|c|c|c|c|}
\hline Variable & Mean & Standard deviation & Min. & Max. & Unit of measurement \\
\hline Net Inflow & 0.009 & 0.117 & -0.442 & 0.981 & $\begin{array}{l}N E_{t}-N E_{t-1} \text { considering the invested return. } \\
\text { Metric from Sirri and Tufano (1998) }\end{array}$ \\
\hline Net Inflow' & 0.008 & 0.112 & -0.434 & 0.929 & Inflow - Redemptions in relation to NE \\
\hline Past Performance & 0.677 & 5.745 & -21.704 & 19.696 & Monthly \% \\
\hline Size of the Fund & 17.193 & 1.653 & 5.785 & 22.717 & Ln of NE \\
\hline Size of the Family & 22.467 & 1.954 & 11.154 & 25.026 & Ln of the family's NE \\
\hline Age & 6.134 & 6.180 & 0.106 & 37.028 & Age in years at the end of each month \\
\hline Inflation & 0.493 & 0.297 & -0.230 & 1.320 & Monthly inflation rate in $\%$ \\
\hline Exchange Rate & 0.715 & 4.592 & -10.717 & 17.126 & Monthly variation of the dollar in \% \\
\hline Real Interest Rate & 0.300 & 0.295 & -0.327 & 1.759 & Monthly interest rate in \% \\
\hline Ibovespa & 0.628 & 6.264 & -24.790 & 17.402 & Monthly return on Ibovespa stocks in \% \\
\hline
\end{tabular}

Note: Number of observations $=184,766$. The Net Inflow variable refers to the metric developed by Sirri and Tufano (1998), while Net Inflow' is a proxy used for robustness analysis purposes.

Source: Elaborated by the authors.

Table 2 contains the result of the regressions that test hypothesis $\mathbf{H}_{1}$ of the study. Three regression models were tested: (i) the first of them contemplates the general sample of the study; (ii) in the second model, only the variables that presented statistical significance in model 1 were tested; (iii) in the third model, the correlated variables were excluded, as well as the variables with no statistical significance. The correlation matrix of the study (as according to Appendix A) indicated a high correlation between the interest rate and inflation variables (0.811). The coefficient of correlation between the Ibovespa (in $t$ ) and the return of the funds in the sample (in $t-1$ ) was 0.077; however, in parallel, from calculating the mean return of the funds per month and correlating this mean return (in $t$ ) with the Ibovespa (in $t$ ), the correlation coefficient was 0.96 , indicating that, although the lagged returns of the funds present a modest correlation with the Ibovespa, the correlation is high when the two variables refer to the same period.

Based on the analysis of the general sample of the stock funds, a positive and statistically significant relationship is observed between net inflow and the dummy for the month of January, which supports hypothesis $\mathbf{H}_{1}$ of this study: the net inflow in the month of January is, on average, greater than the net inflow in other months of the year. The effect was persistent in the three models tested.

It is thus suggested that the January effect seasonality already shown in the return on equities in different financial markets (Al-Khazali \& Mirzaei, 2017; Caporale \& Zakirova, 2017; Easterday \& Sen, 2016; Seif et al., 2017; Shiu et al., 2014) can also be observed in the net inflow of mutual funds that invest most of the assets of their portfolios in the stock exchange, since the average net inflow of these funds was statistically greater in the month of January than in other months of the year.

The result supports the recent empirical literature, which revealed the possibility of the occurrence of seasonalities also in the fund industry (Alves, 2014; Białkowski et al., 2013; Brown et al., 2017; Choi, 2015; Choi et al., 2017; Gallagher \& Pinnuck, 2006; Kamstra et al., 2017; Malaquias \& Mamede, 2015; Mamede \& Malaquias, 2017; Matallín-Sáez, 2006; Vidal-García \& Vidal, 2014). 
Table 2

Results for the panel data regression analysis

\begin{tabular}{|c|c|c|c|c|}
\hline \multirow[b]{2}{*}{ Variables of the model } & \multicolumn{4}{|c|}{ Regression models } \\
\hline & Expected sign & $\begin{array}{c}\text { NINF } \\
\text { General sample }\end{array}$ & $\begin{array}{c}\text { NINF } \\
\text { Significant variables }\end{array}$ & $\begin{array}{c}\text { NINF } \\
\text { Non-correlated variables }\end{array}$ \\
\hline January Dummy & $(+) / \mathrm{n} . \mathrm{s}$ & $\begin{array}{c}0.005^{* * *} \\
(4.450)\end{array}$ & $\begin{array}{c}0.005 * * * \\
(4.450)\end{array}$ & $\begin{array}{c}0.003^{* * *} \\
(2.890)\end{array}$ \\
\hline Size of the Fund & $(+)$ & $\begin{array}{c}0.001 * * \\
(2.930)\end{array}$ & $\begin{array}{c}0.001 * * \\
(3.280)\end{array}$ & $\begin{array}{c}0.001 * * * \\
(3.750)\end{array}$ \\
\hline Age of the Fund & $(+)$ & $\begin{array}{c}-0.004 * * * \\
(-5.080)\end{array}$ & $\begin{array}{c}-0.004^{* * *} \\
(-5.060)\end{array}$ & $\begin{array}{c}-0.004^{* * *} \\
(-4.730)\end{array}$ \\
\hline Performance Fee & $(+)$ & $\begin{array}{l}-0.0004 \\
(-0.160)\end{array}$ & -- & -- \\
\hline Size of the Fund's Family & $(+)$ & $\begin{array}{l}0.0003 \\
(0.700)\end{array}$ & -- & -- \\
\hline Past Performance & $(+)$ & $\begin{array}{l}0.001 * * * \\
(21.770)\end{array}$ & $\begin{array}{c}-0.001 * * * \\
(21.780)\end{array}$ & $\begin{array}{l}0.001 * * * \\
(23.070)\end{array}$ \\
\hline Inflation & $(-)$ & $\begin{array}{c}-0.025^{* * *} \\
(-9.100)\end{array}$ & $\begin{array}{c}-0.025^{* * *} \\
(-9.110)\end{array}$ & -- \\
\hline Interest Rate & $(-)$ & $\begin{array}{c}-0.025^{* * *} \\
(-9.440)\end{array}$ & $\begin{array}{c}-0.025 * * * \\
(-9.480)\end{array}$ & -- \\
\hline Exchange Rate & $(-)$ & $\begin{array}{c}-0.0004^{* * *} \\
(-5.810)\end{array}$ & $\begin{array}{c}-\mathbf{0 . 0 0 0 4}{ }^{* * *} \\
(-5.800)\end{array}$ & $\begin{array}{c}-0.0005^{* * *} \\
(-6.120)\end{array}$ \\
\hline Ibovespa & $(+)$ & $\begin{array}{c}-0.003^{* * *} \\
(-6.950)\end{array}$ & $\begin{array}{c}-0.001^{* * *} \\
(-6.920)\end{array}$ & $\begin{array}{c}-0.0003^{* *} \\
(-6.230)\end{array}$ \\
\hline Constant & & $\begin{array}{l}-0.017 \\
(1.440)\end{array}$ & $\begin{array}{l}0.022 * * \\
(2.880)\end{array}$ & $\begin{array}{c}-0.006 \\
(-0.890)\end{array}$ \\
\hline$N$ & & 181,765 & 182,083 & 182,083 \\
\hline \multirow{3}{*}{$\mathrm{R}^{2}$} & Within & 0.030 & 0.030 & 0.029 \\
\hline & Between & 0.036 & 0.035 & 0.034 \\
\hline & Overall & 0.022 & 0.022 & 0.023 \\
\hline
\end{tabular}

Note: ${ }^{*}, *$, and ${ }^{* * *}$ indicate significance at $10 \%, 5 \%$, and $1 \%$, respectively. Values in bold have statistical significance. Dummies for year were used for the 3 regression models. The dependent variable Net Inflow was measured in the three models using the metric developed by Sirri and Tufano (1998). The regressions were estimated using the fixed effects model. Values in parentheses refer to the $t$ statistics.

Source: Elaborated by the authors.

Backed by the literature, it is suggested that the phenomenon could be related to factors such as the increase in income and consumption of investors at the end of the year, to the performance of equity mutual funds in the month of December, the tax treatment of the investor based on the distribution of capital of funds (Choi et al., 2017), a reflection of the seasonal pattern of the stock market or of fund performance, or it could even be due to a behavioral component of fund investors, since most of these would make their investment decisions and revise their portfolios at the turn of the year (Choi, 2015).

In addition, seen from the perspective of the market efficiency theoretical line of thinking, the rejection of hypothesis $\mathbf{H}_{0}$ in favor of $\mathbf{H}_{1}$ - which demonstrates that standards of behavior and predictable variables of financial assets could also be found in the fund industry at regular calendar intervals, such as in a particular month of the year - would be considered an anomalous behavior, which contradicts the assumptions of market efficiency (Fama, 1970), as it is not based on rational decisions of economic agents (Keim, 1983) and is not explained by any existing theory (Zhang, Lai \& Lin, 2017).

In practical terms, the result of hypothesis $\mathbf{H}_{1}$ of the study suggests that the volume of capital invested in shares in equity funds after deducting the redemptions made in the month tends to be greater in the month of January than in other months of the year. This may occur due to both the high volumes invested in the month and because of the low redemptions value. For managers, recognizing the existence of this seasonal pattern in equity funds enables variations to be anticipated so that their effects on performance are reduced.

The analysis of the control variables of the general regression suggests that all the variables used by the study 
are statistically significant for explaining variations in the net inflow of the general sample, except performance fee and size of the fund's family. As expected based on the literature review on funds, the fund's size (Barber et al., 2005; Chevalier \& Ellison, 1997; Ferreira et al., 2012; Sirri \& Tufano, 1998) and past performance (Berggrun \& Lizarzaburu, 2015; Ferreira et al., 2012; Goetzmann \& Peles, 1997) have a positive relationship with net inflow, while inflation (Brandt \& Wang, 2003; Krishnamurthy et al., 2018), the interest rate (Cecchetti et al., 2000; Hau \& Lai, 2016), and the exchange rate (Ferson \& Kim, 2012; Krishnamurthy et al., 2018) have a negative relationship with the dependent variable. On the other hand, the negative relationship found between the fund's age (Barber et al., 2005; Berggrun \& Lizarzaburu, 2015; Chevalier \& Ellison, 1997; Ferreira et al., 2012), the Ibovespa index (Choi et al., 2017, Maestri \& Malaquias, 2017), and the net inflow would go against expectations.

Thus, concerning the characteristics inherent to mutual funds, the results indicate that larger funds and those performing better in the previous month would have, on average, a greater net inflow, while older funds would have, on average, a lower net inflow. Regarding the factors that are extrinsic to funds, the results support studies that indicate that macroeconomic variables have an influence on the investment decisions of fund shareholders (Ferson \& Kim, 2012; Chalmers et al., 2013; Krishnamurthy et al., 2018); the higher the rate of inflation, the interest rate, and the exchange rate, the lower the net inflow of Brazilian equity funds tends to be.

Through the regression analysis of the models presented in Table 3 it was possible to analyze hypothesis $\mathbf{H}_{2}$ of the study. We chose to estimate two regressions so as to observe the behavior of the January effect in two different subsamples, one with exclusive funds and another with nonexclusive funds. The relationship between the net inflow of the exclusive funds and the dummy for the month of January did not present statistical significance, while the same relationship for the sample of non-exclusive funds continued to be positive and significant, as occurred in the general sample. In general, this result is in line with $\mathbf{H}_{2}$, given that the effect occurs in the subsample of non-exclusive funds (being positive and significant), but is statistically non-significant in a subsample of exclusive funds.

Table 3

Comparison between Exclusive and Non-Exclusive Funds

\begin{tabular}{|c|c|c|c|}
\hline Variables of the model & Expected sign & Non-Exclusive Funds Subsample & Exclusive Funds Subsample \\
\hline January Dummy & $(+) / \mathrm{n} . \mathrm{s}$ & $\begin{array}{c}0.005^{* * *} \\
(4.070)\end{array}$ & $\begin{array}{c}0.004 \\
(1.670)\end{array}$ \\
\hline Size of the Fund & $(+)$ & $\begin{array}{l}-0.0004 \\
(-1.180)\end{array}$ & $\begin{array}{l}0.022 * * * \\
(20.470)\end{array}$ \\
\hline Age of the Fund & $(+)$ & $\begin{array}{c}-0.004^{* * *} \\
(-4.960)\end{array}$ & $\begin{array}{c}-0.003 \\
(-1.240) \\
\end{array}$ \\
\hline Performance Fee & $(+)$ & $\begin{array}{c}0.005 \\
(1.280)\end{array}$ & $\begin{array}{c}0.004 \\
(1.140)\end{array}$ \\
\hline Size of the Fund's Family & $(+)$ & $\begin{array}{l}-0.001 \\
(-1.310)\end{array}$ & $\begin{array}{l}-0.0004 \\
(-0.500)\end{array}$ \\
\hline Past Performance & $(+)$ & $\begin{array}{l}0.001 * * * \\
(23.070)\end{array}$ & $\begin{array}{l}-0.0002^{* *} \\
(-2.570)\end{array}$ \\
\hline Inflation & $(-)$ & $\begin{array}{c}-0.027^{* * *} \\
(-9.140)\end{array}$ & $\begin{array}{l}-0.010 \\
(-1.670)\end{array}$ \\
\hline Interest Rate & $(-)$ & $\begin{array}{c}-0.028^{* * *} \\
(-9.700)\end{array}$ & $\begin{array}{l}-0.007 \\
(-1.200)\end{array}$ \\
\hline Exchange Rate & $(-)$ & $\begin{array}{c}-0.0001^{* * *} \\
(-6.000)\end{array}$ & $\begin{array}{c}-0.000 \\
(-0.090)\end{array}$ \\
\hline Ibovespa & $(+)$ & $\begin{array}{l}-0.0003 * * * \\
(-6.180)\end{array}$ & $\begin{array}{l}-0.0003 * * * \\
(-3.830)\end{array}$ \\
\hline Constant & & $\begin{array}{c}0.070^{* * *} \\
(5.240)\end{array}$ & $\begin{array}{l}-0.372^{* * *} \\
(-13.900)\end{array}$ \\
\hline $\mathrm{N}$ & & 160,180 & 21,585 \\
\hline \multirow{3}{*}{$\mathrm{R}^{2}$} & Within & 0.033 & 0.029 \\
\hline & Between & 0.035 & 0.003 \\
\hline & Overall & 0.025 & 0.010 \\
\hline
\end{tabular}

Note: ${ }^{*}, * *$, and ${ }^{* * *}$ indicate significance at 10\%,5\%, and 1\%, respectively. Values in bold have statistical significance. Dummies for year were used in the models. The dependent variable Net Inflow was measured using the metric developed by Sirri and Tufano (1998). The fixed effects model was used. Values in parentheses refer to the $t$ statistics.

Source: Elaborated by the authors. 
Besides the differences also revealed by the literature between exclusive and non-exclusive funds in terms of performance (Chen \& Malaquias, 2018) and risk (Funchal et al., 2016), due to the differences in manager behavior, it is suggested that the seasonality of the month of January, in terms of net inflow, is not present in exclusive funds. On the other hand, the net inflow of the non-exclusive funds presents seasonal behavior in the month, and is, on average, greater than the net inflow in other months of the year.

Possible explanations for the difference in seasonality observed between the two types of funds may be related to the fact that: (i) funds with contributions from single shareholders would be susceptible to smaller variations in net inflow than funds in which the investors are more fragmented and could redeem or buy new shares more often; and (ii) shareholders of exclusive funds are generally long-term investors, which tend to hold capital in these funds unless something unfavorable and serious occurs in their financial situation. This certain stability in the capital would have as ramifications lower levels of change in net inflow, including in the month of January.

\subsection{Robustness Analysis}

According to regression model 1, presented in Appendix B, when using a second metric for measuring the net inflow of the stock funds, the results continued to be the same: the signs obtained for the variables were the same, as were the statistical significances. In this model, the January effect on equity fund flows was also revealed.

Based on regression models 2 and 3 (Appendix C), the seasonality presented by the January effect is observed both in the sample of closed and/or started funds and in the sample of surviving funds. Thus, it is suggested that the January effect on net inflow would not derive from the opening or closing of funds, but probably from the allocation and reallocation of resources of fund shareholders that are operating in the financial market. Excluding from the sample the equity mutual funds that invest in shares in other funds (FICs), the results showed that the January effect was persistent (Appendix C, Model 4).

The main results of the study thus indicate that: (i) the average net inflow of Brazilian equity funds is greater in January than in other months of the year, which characterizes the existence of a seasonal pattern in the net flow of these funds, known as the "January effect"; (ii) the effect of the seasonality presented in the month of January is different in exclusive and non-exclusive funds, suggesting that shareholders in exclusive funds are less susceptible to rebalancing their investments in response to occurrences in the financial market, specifically at the start of the year; (iii) the type of investor of exclusive funds is not necessarily influenced by the same variables as investors in non-exclusive funds when they make their investment decisions; (iv) investors in equity funds are sensitive to macroeconomic variations when allocating their portfolios. After running robustness tests, the results continued to be the same.

\section{CONCLUSIONS}

Although the number of studies that investigate occurrences of seasonalities and/or possible patterns of behavior in various financial market assets has grown in the last few years, in Brazil, studies on these seasonal effects are still less prominent; those that cover the growing Brazilian fund industry are even less frequent. In this context, the aim of this study was to analyze the relationship between the known seasonality presented by the January effect in the stock market and equity fund flows. In addition, it investigated whether the seasonality of the month of January could have a different effect on the net inflow of exclusive and non-exclusive funds.

The results suggest that the evidence of the seasonal effects of the month of January already observed in the stock market (Al-Khazali \& Mirzaei, 2017; Caporale \& Zakirova, 2017; Easterday \& Sen, 2016; Seif et al., 2017; Shiu et al., 2014), in other financial market assets
(Caporale \& Zakirova, 2017; Kumar, 2016; Zaremba \& Schabek, 2017), and in international equity mutual funds (Choi, 2015; Choi et al., 2017) may also be extended to Brazilian equity funds: it was found that the net inflow in the month of January is, on average, greater than the net inflow in other months of the year.

Aspects that could explain the seasonality found in the month of January are: (i) the increase in income and consumption of investors at the end of the year; (ii) the performance of equity mutual funds in the month of December; (iii) the tax treatment of the investor based on the distributions of capital of funds (Choi et al., 2017); (iv) the reflection of the seasonal pattern of the stock market or fund performance; or, even (v) a behavioral component of fund investors, which would tend to make their investment decisions and revise their portfolios at the turn of the year (Choi, 2015). 
The results also indicate that the effect of the month of January on net inflow is different in exclusive and nonexclusive funds; if on one hand no statistical relationship was found between net inflow and the January effect in exclusive funds, on the other, it was found that the net inflow of non-exclusive funds is, on average, greater in January than in other months of the year. This result supports the literature, which shows differences in the management and workings of these two types of funds (Chen \& Malaquias, 2018; Funchal et al., 2016).

The analysis of the control variables of the study also brought innovative contributions to the literature: international studies use as explanatory factors for the variations in net inflow some variables that had not yet been tested, as far as we know, for the Brazilian fund industry, for example macroeconomic aspects, such as inflation, interest rate, and exchange rate (Hau \& Lai, 2016; Krishnamurthy et al., 2018). The results indicated the existence of a negative relationship between inflation, interest rate, and exchange rate and net inflow, indicating that any deterioration in the economic scenario, the government choosing a contractionary monetary policy, and an increase in the return on the dollar would present negative effects for the net inflow of stock funds in the country.

In other words, the results of the research characterized the existence of a seasonal pattern in the net flow of Brazilian funds, the so-called "January effect". It was shown that shareholders in exclusive funds would be less susceptible to rebalancing their investments in response to occurrences in the financial market, specifically at the start of the year, and they would also not necessarily be influenced by the same variables as investors in nonexclusive funds when making their investment decisions. Regarding investors in non-exclusive funds, these are sensitive to macroeconomic variations when making resource allocation decisions.

Finally, it warrants mentioning the cases of an alteration in the flow of funds derived from the redemption or buying of shares in other funds, including funds from other categories, and vice-versa. These alterations may especially occur in light of variations in the market interest rate, indicating better investment opportunities in fixed income funds or in equity funds, for example. Thus, the quantitative model considered in this study uses the interest rate as a control variable: the estimates suggest that in periods with higher market interest rates, investors appear to redeem their shares in stock funds; on the other hand, the financial inputs, on average, increased in the stock funds in the sample in periods with lower interest rates. Although using the interest rate may represent the market's behavior, there are opportunities for new studies considering as possible determinants of equity fund flows variables directly related with the net flow of funds from different categories.

For future research, we also suggest that possible explanations for the occurrence of the seasonality in the month of January in equity mutual funds are empirically tested, which could even be done using qualitative studies.

\section{REFERENCES}

Ackermann, C., Mcenally, R., \& Ravenscraft, D. (1999). The performance of hedge funds: risk, return, and incentives. The Journal of Finance, 54(3), 833-874.

Agrawal, A., \& Tandon, K. (1994). Anomalies or illusions? Evidence from stock markets in eighteen countries. Journal of International Money and Finance, 13(1), 83-106.

Al-Khazali, O. M., Koumanakos, E. P., \& Pyun, C. S. (2008). Calendar anomaly in the Greek stock market: stochastic dominance analysis. International Review of Financial Analysis, 17(3), 461-474.

Al-Khazali, O., \& Mirzaei, A. (2017). Stock market anomalies, market efficiency and the adaptive market hypothesis: evidence from Islamic stock indices. Journal of International Financial Markets, Institutions \& Money, 51(C), 190-208.

Alves, C. F. (2014). Evidence for the seasonality of European equity fund performance. Applied Economics Letters, 21(16), 1156-1160.

Associação Brasileira das Entidades dos Mercados Financeiro e de Capitais. (2018, dezembro). Consolidado Histórico de Fundos de Investimento. Retrieved from https://www.anbima.com. br/pt_br/informar/estatisticas/fundos-de-investimento/ficonsolidado-historico.htm

Barber, B. M., Odean, T., \& Zheng, L. (2005). Out of sight, out of mind: the effects of expenses on mutual fund flows. The Journal of Business, 78(6), 2095-2120.

Berggrun, L., \& Lizarzaburu, E. (2015). Fund flows and performance in Brazil. Journal of Business Research, 68(2), 199-207.

Białkowski, J., Bohl, M. T., Kaufmann, P., \& Wisniewski, T. P. (2013). Do mutual fund managers exploit the Ramadan anomaly? Evidence from Turkey. Emerging Markets Review, 15, 211-232.

Brandt, M. W., \& Wang, K. Q. (2003). Time-varying risk aversion and unexpected inflation. Journal of Monetary Economics, 50, 1457-1498.

Brown, S. J., Sotes-Paladino, J., Wang, J. G., \& Yao, Y. (2017). Starting on the wrong foot: seasonality in mutual fund performance. Journal of Banking and Finance, 82, 133-150. 
Caporale, G. M., \& Zakirova, V. (2017). Calendar anomalies in the Russian stock market. Russian Journal of Economics, 3, 101-108.

Carvalho, L. F., \& Malaquias, R. F. (2012). Anomalias de calendário no mercado brasileiro: uma análise com empresas pertencentes ao IGC. Revista Contemporânea de Economia e Gestão, 10(2), 25-35.

Cecchetti, S. G., Genberg, H., Lipsky, J., \& Wadhwani, S. (2000). Asset prices and Central Bank policy (Geneva Reports on the World Economy No. 2). Geneva, Switzerland: International Centre for Monetary and Banking Studies.

Chalmers, J., Kaul, A., \& Phillips, B. (2013). The wisdom of crowds: mutual fund investors' aggregate asset allocation decisions. Journal of Banking \& Finance, 37, 3318-3333.

Chen, H., \& Malaquias, R. F. (2018). Does individual fund shareholder structure matter? A study of exclusive funds in Brazil. Review of Economics and Finance, 12(2), 1-15.

Chevalier, J., \& Ellison, G. (1997). Risk taking by mutual funds as a response to incentives. Journal of Political Economy, 105, 1167-1200.

Choi, H.-S. (2015). Seasonality in mutual fund flows. The Journal of Applied Business Research, 31(2), 715-726.

Choi, H.-S., Ryu, D., \& Seok, S. (2017). The turn-of-the-year effect in mutual fund flows. Risk Management, 10(2), 131-158.

Comissão de Valores Mobiliários (Brazilian Securities and Exchange Commission). (2014, December 17). CVM Instruction $n$. 555. Describes the constitution, administration, workings, and disclosure of information of investment funds. Rio de Janeiro, RJ: Autor.

Costa, N. C. A., Jr. (1990). Sazonalidades do Ibovespa. Revista de Administração de Empresas, 30(3), 79-84.

Costa, N. C. A., Jr., \& O’Hanlon, J. (1991). O efeito tamanho versus o efeito mês-do-ano no mercado de capitais brasileiro: uma análise empírica. Revista Brasileira de Mercado de Capitais, 16(43), 61-74.

Easterday, K. E., \& Sen, P. K (2016). Is the January effect rational? Insights from the accounting valuation model. The Quarterly Review of Economics and Finance, 59, 168-185.

Fama, E. F. (1970). Efficient capital markets: a review of theory and empirical work. The Journal of Finance, 25(2), 383-417.

Fama, E. F. (1981). Stock returns, real activity, inflation, and money. The American Economic Review, 71(4), 545-565.

Ferreira, M. A., Keswani, K., Miguel, A. F., \& Ramos, S. B. (2012). The flow-performance relationship around the world. Journal of Banking \& Finance, 36, 1759-1780.

Ferson, W. E., \& Kim, M. S. (2012). The factor structure of mutual fund flows. International Journal of Portfolio Analysis and Management, 1(2), 112-143.

Funchal, B., Lourenço, D., \& Motoki, F. Y. S. (2016). Sofisticação dos investidores, liberdade de movimentação e risco: um estudo do mercado brasileiro de fundos de investimento em ações. Revista de Contabilidade e Organizações, 28, 45-57.

Gallagher, D. R., \& Pinnuck, M. (2006). Seasonality in fund performance: an examination of the portfolio holdings and trades of investment managers. Journal of Business Finance \& Accounting, 33(7), 1240-1266.
Goetzmann W. N., \& Peles, N. (1997). Cognitive dissonance and mutual fund investors. The Journal of Financial Research, 20(2), 145-158.

Grossi, J. C. (2018). Os anos mudam mas o efeito continua o mesmo em todos os meses de janeiro? Uma análise de sazonalidade e do fluxo financeiro dos fundos de ações brasileiros (Master's Thesis). Faculdade de Gestão e Negócios, Universidade Federal de Uberlândia, Uberlândia.

Gultekin, M. N., \& Gultekin, N. B. (1983). Stock market seasonality: international evidence. Journal of Financial Economics, 12(4), 469-481.

Hau, H., \& Lai, S. (2016). Asset allocation and monetary policy: evidence from the Eurozone. Journal of Financial Economics, 120(2), 309-329.

Ippolito, R. A. (1989). Efficiency with costly information: a study of mutual fund performance, 1965-1984. Quarterly Journal of Economics, 104, 1-23.

Kamstra, M. J., Kramer, L. A., Levi, M. D., \& Wermers, R. (2017). Seasonal asset allocation: evidence from mutual fund flows. Journal of Financial and Quantitative Analysis, 52(1), 71-109.

Keim, D. (1983). Size-related anomalies and stock return seasonality: further empirical evidence. Journal of Financial Economics, 12, 473-490.

Krishnamurthy, S., Pelletier, D., \& Warr, R. (2018). Inflation and equity mutual fund flows. Journal of Financial Markets, 37, $52-69$.

Krugman, P. R, Obstfeld, M., \& Melitz, M. J. (2014). International economics theory and policy (10a ed.). New York, NY: Pearson.

Kumar, S. (2016). Revisiting calendar anomalies: three decades of multicurrency evidence. Journal of Economics and Business, $86,16-32$.

Maestri, C. O. N. M., \& Malaquias, R. F. (2017). Exposição a fatores de mercado de fundos de investimentos no Brasil. Revista Contabilidade \& Finanças, 28(73), 61-76.

Malaquias, R. F., \& Mamede, S. P. N. (2015). Efeito calendário e finanças comportamentais no segmento de fundos multimercados. Revista de Administração Contemporânea, 19(Especial), 98-116.

Mamede, S. P. N., \& Malaquias, R. F. (2017). Monday effect in Brazilian hedge funds with immediate redemption. Research in International Business and Finance, 39, 47-53.

Matallín-Sáez, J. C. (2006). Seasonality, market timing and performance amongst benchmarks and mutual fund evaluation. Journal of Business Finance \& Accounting, 33(9), 0306-686X.

Potin, A. S., Potin, S., Cunha, C. M. P, \& Bortolon, P. M. (2015). Efeito janeiro nas ações e ADRs de empresas brasileiras após o início da tributação de ganhos de capital. REAd, 81(2), 320347.

Rozeff, M. S., \& Kinney, W. (1976). Capital market seasonality: the case of stock returns. Journal of Financial Economics, 3(4), $379-402$.

Santos, J. O., Famá, R., Trovão, R., \& Mussa, A. (2007, julho). Anomalias do mercado acionário brasileiro: a verificação do efeito janeiro no Ibovespa no período de 1969 a 2006. In Anais do 7 Encontro Brasileiro de Finanças. São Paulo, SP. 
Seif, M., Docherty, P., \& Shamsuddin, A. (2017). Seasonal anomalies in advanced emerging stock markets. The Quarterly Review of Economics and Finance, 66, 169-181.

Shiu, Y., Lee, C. I., \& Gleason, K. C. (2014). Institutional shareholdings and the January effects in Taiwan. Journal of Multinational Finance Management, 27, 49-66.
Varga, G., \& Wengert, M. (2011). A indústria de fundos de investimentos no Brasil. Revista de Economia e Administração, 10(1), 66-109.

Vidal-García, J., \& Vidal, M. (2014). Seasonality and idiosyncratic risk in mutual fund performance. European Journal of Operational Research, 233, 613-624.

Sirri, E., \& Tufano, P. (1998). Costly search and mutual fund flows. Wachtel, S. B. (1942). Certain observations on seasonal Journal of Finance, 53, 1589-1622. movements in stock prices. The Journal of Business, 15, 184

Thaler, R. H. (1987). Anomalies: the January Effect. The Journal of Economic Perspectives, 1(1), 197-201.

Torres, R., Bonomo, M., \& Fernandes, C. (2002). A aleatoriedade do passeio na Bovespa: testando a eficiência do mercado acionário brasileiro. Revista Brasileira de Economia, 56(2), 199-247.
Zaremba, A., \& Schabek, T. (2017). Seasonality in government bond returns and factor premia. Research in International Business and Finance, 41, 292-302.

Zhang, J., Lai, Y., \& Lin, J. (2017). The day-of-the-week effects of stock markets in different countries. Finance Research Letters, $20,47-62$.

\section{APPENDIX A}

Correlation matrix

\begin{tabular}{|c|c|c|c|c|c|c|c|c|c|c|c|c|}
\hline & Net Inf. & Net Inf.' & $\begin{array}{c}\text { Jan. } \\
\text { Dummy }\end{array}$ & $\begin{array}{l}\text { Past } \\
\text { Perf. }\end{array}$ & Perf. Fee & $\begin{array}{l}\text { Fund } \\
\text { Size }\end{array}$ & Age & $\begin{array}{l}\text { Family } \\
\text { Size }\end{array}$ & Inflation & $\begin{array}{l}\text { Exch. } \\
\text { Rate }\end{array}$ & Int. Rate & Ibovespa \\
\hline Net Inf. & 1 & & & & & & & & & & & \\
\hline Net Inf.' & 0.9697 & 1 & & & & & & & & & & \\
\hline $\begin{array}{l}\text { Jan. } \\
\text { Dummy }\end{array}$ & 0.0083 & 0.0102 & 1 & & & & & & & & & \\
\hline $\begin{array}{l}\text { Past } \\
\text { Perf. }\end{array}$ & 0.068 & 0.0657 & -0.001 & 1 & & & & & & & & \\
\hline Perf. Fee & 0.0182 & 0.0178 & -0.0012 & -0.0013 & 1 & & & & & & & \\
\hline $\begin{array}{l}\text { Fund } \\
\text { Size }\end{array}$ & 0.0204 & 0.0197 & -0.0037 & 0.0516 & -0.0735 & 1 & & & & & & \\
\hline Age & -0.0944 & -0.0959 & 0.0005 & -0.0105 & -0.1481 & 0.0891 & 1 & & & & & \\
\hline $\begin{array}{l}\text { Family } \\
\text { Size }\end{array}$ & 0.0124 & 0.0123 & -0.005 & 0.0139 & 0.1034 & 0.2546 & -0.1495 & 1 & & & & \\
\hline Inflation & -0.0441 & 0.0443 & 0.2361 & -0.0645 & 0.0148 & -0.0565 & -0.0276 & 0.012 & 1 & & & \\
\hline $\begin{array}{l}\text { Exch. } \\
\text { Rate }\end{array}$ & -0.0248 & -0.0182 & 0.0911 & -0.0331 & 0.0096 & -0.0172 & -0.007 & 0.0314 & 0.0926 & 1 & & \\
\hline Int. Rate & 0.0055 & 0.0063 & 0.1699 & 0.0104 & -0.0193 & -0.0012 & 0.0395 & -0.0928 & -0.811 & -0.0659 & 1 & \\
\hline Ibovespa & 0.0036 & 0.0038 & 0.0335 & 0.0777 & -0.0033 & 0.0123 & 0.0179 & -0.0036 & -0.1407 & -0.6262 & 0.1036 & 1 \\
\hline
\end{tabular}

Source: Elaborated by the authors. 


\section{APPENDIX B}

Regression with another proxy for net inflow

\begin{tabular}{|c|c|c|}
\hline Variables of the model & & Model 1 - Net Inflow' \\
\hline January Dummy & & $\begin{array}{c}0.006 * * * \\
(6.250)\end{array}$ \\
\hline Size of the Fund & & $\begin{array}{c}0.001 * * * \\
(3.870)\end{array}$ \\
\hline Age of the Fund & & $\begin{array}{c}-0.003 * * * \\
(-19.050)\end{array}$ \\
\hline Performance Fee & & $\begin{array}{c}-0.001 \\
(-0.930)\end{array}$ \\
\hline Size of the Fund's Family & & $\begin{array}{c}-0.00004 \\
(1.190)\end{array}$ \\
\hline Past Performance & & $\begin{array}{c}0.0001 * * * \\
(20.000)\end{array}$ \\
\hline Inflation & & $\begin{array}{c}-0.027^{* * *} \\
(-10.420) \\
\end{array}$ \\
\hline Interest Rate & & $\begin{array}{c}-0.027^{* * *} \\
(-10.690)\end{array}$ \\
\hline Exchange Rate & & $\begin{array}{c}-0.0003 * * * \\
(-4.370)\end{array}$ \\
\hline Ibovespa & & $\begin{array}{c}-0.0004^{* * *} \\
(-8.490) \\
\end{array}$ \\
\hline Constant & & $\begin{array}{c}0.025^{* *} \\
(2.840)\end{array}$ \\
\hline $\mathrm{N}$ & & 179,208 \\
\hline \multirow{3}{*}{$\mathrm{R}^{2}$} & Within & 0.030 \\
\hline & Between & 0.038 \\
\hline & Overall & 0.027 \\
\hline
\end{tabular}

Note: *,*, and ${ }^{* * *}$ indicate significance at 10\%,5\%, and 1\%, respectively. Values in bold have statistical significance. A dummy for year was used. An alternative proxy was used for net inflow. Values in parenthesis refer to the $t$ statistics.

Source: Elaborated by the authors. 


\section{APPENDIX C}

Regressions for robustness tests

\begin{tabular}{|c|c|c|c|c|}
\hline \multirow[b]{2}{*}{ Variables of the model } & & \multicolumn{3}{|c|}{ Regression models for robustness tests } \\
\hline & & $\begin{array}{l}\text { Model } 2 \text { - Started and/or } \\
\text { Closed Funds Sample }\end{array}$ & $\begin{array}{l}\text { Model } 3 \text { - Surviving } \\
\text { Funds Sample }\end{array}$ & $\begin{array}{c}\text { Model } 4 \text { - Sample } \\
\text { without FICs }\end{array}$ \\
\hline January Dummy & & $\begin{array}{c}0.005^{* * *} \\
(4.710)\end{array}$ & $\begin{array}{c}0.005^{* *} \\
(2.400)\end{array}$ & $\begin{array}{l}0.005^{* *} \\
(3.460)\end{array}$ \\
\hline Size of the Fund & & $\begin{array}{c}0.002 * * * \\
(5.090)\end{array}$ & $\begin{array}{c}0.002 * * * \\
(4.490)\end{array}$ & $\begin{array}{c}0.005 \\
(10.000)^{* * *}\end{array}$ \\
\hline Age of the Fund & & $\begin{array}{l}-0.003 * * * \\
(-19.270)\end{array}$ & $\begin{array}{c}0.000 \\
(-0.450) \\
\end{array}$ & $\begin{array}{l}-0.003^{*} \\
(-2.560) \\
\end{array}$ \\
\hline Performance Fee & & $\begin{array}{c}0.002 \\
(1.280) \\
\end{array}$ & $\begin{array}{l}-0.0004 \\
(-0.220)\end{array}$ & $\begin{array}{l}-0.003 \\
(-0.438)\end{array}$ \\
\hline Size of the Fund's Family & & $\begin{array}{c}0.001 * * \\
(2.570)\end{array}$ & $\begin{array}{l}0.0003 \\
(-0.670) \\
\end{array}$ & $\begin{array}{c}0.001 \\
(1.810) \\
\end{array}$ \\
\hline Past Performance & & $\begin{array}{l}0.001 * * * \\
(18.840)\end{array}$ & $\begin{array}{l}0.001 * * * \\
(12.990)\end{array}$ & $\begin{array}{l}0.001 * * \\
(14.370)\end{array}$ \\
\hline Inflation & & $\begin{array}{l}-0.027^{* * *} \\
(-9.120)\end{array}$ & $\begin{array}{l}-0.003 \\
(-0.500)\end{array}$ & $\begin{array}{c}-0.018^{* * *} \\
(-5.180)\end{array}$ \\
\hline Interest Rate & & $\begin{array}{c}-0.028^{* * *} \\
(-9.530)\end{array}$ & $\begin{array}{c}-0.004 \\
(-0.850) \\
\end{array}$ & $\begin{array}{c}-0.018^{* * *} \\
(-5.430)\end{array}$ \\
\hline Exchange Rate & & $\begin{array}{c}-0.0004^{* * *} \\
(-5.190)\end{array}$ & $\begin{array}{c}-0.001 * * \\
(-3.680)\end{array}$ & $\begin{array}{c}0.000 * * * \\
(-4.360)\end{array}$ \\
\hline Ibovespa & & $\begin{array}{l}-0.0003 * * * \\
(-5.930)\end{array}$ & $\begin{array}{l}-0.0004 * * * \\
(-3.770)\end{array}$ & $\begin{array}{c}0.000 * * * \\
(-6.560)\end{array}$ \\
\hline Constant & & $\begin{array}{c}-0.005 \\
(-0.510) \\
\end{array}$ & $\begin{array}{c}-0.027^{* *} \\
(-2.030) \\
\end{array}$ & $\begin{array}{c}-0.072^{* * *} \\
(-5.180) \\
\end{array}$ \\
\hline $\mathrm{N}$ & & 161,581 & 20,184 & 114,153 \\
\hline \multirow{3}{*}{$\mathrm{R}^{2}$} & Within & 0.032 & 0.043 & 0.026 \\
\hline & Between & 0.033 & 0.032 & 0.017 \\
\hline & Overall & 0.027 & 0.042 & 0.021 \\
\hline
\end{tabular}

Note: *,*, and ${ }^{* * *}$ indicate significance at 10\%, 5\%, and 1\%, respectively. Values in bold have statistical significance. Dummies for year were used for the 3 regression models. The dependent variables of models 2, 3, and 4 were estimated using the metric developed by Sirri and Tufano (1998), as specified in the methodology. Values in parentheses refer to the $t$ statistics.

Source: Elaborated by the authors. 